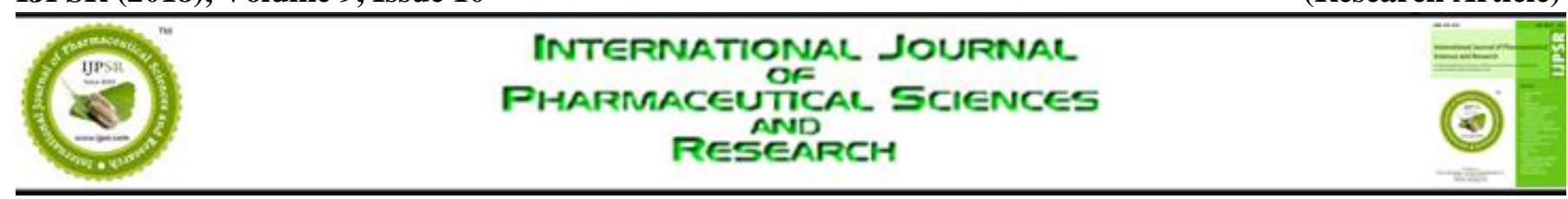

Received on 10 February, 2018; received in revised form, 27 August, 2018; accepted, 02 September, 2018; published 01 October, 2018

\title{
FORMULATION AND EVALUATION OF SUSTAINED RELEASE MATRIX TABLETS OF BACLOFEN
}

K. Ravi Shankar ${ }^{*}{ }^{1}$, K. Madhan ${ }^{1}$ and G. Swetha ${ }^{2}$

Department of Pharmaceutics ${ }^{1}$, Department of Pharmaceutical Analysis ${ }^{2}$, K. L. R. Pharmacy College, Paloncha - 507115, Telangana, India.

Keywords:

Sustained release,

Matrix tablets, HPMC K4M, HPMC K15, Sodium alginate, Mannitol

Correspondence to Author:

K. Ravi Shankar

H. No. 17-4-55, Punjabgadda,

Ramavaram, Kothagudem

Bhadradri Kothagudem - 507118,

Telangana, India.

E-mail: rskar009@gmail.com

\begin{abstract}
The objective of the present study is to develop a pharmaceutically stable sustained release matrix tablets of Baclofen and perform the pre-compression, post compression and in-vitro evaluation studies of developed formulation. In this study sustained release matrix tablets of Baclofen were prepared by wet granulation method using mannitol, HPMC K4M, sodium alginate, HPMC $\mathrm{K} 15$ in various concentrations. All the formulations have showed acceptable Pharmacopeial standards. Formulation F9 have extended the release of Baclofen upto $12 \mathrm{~h}$. Model fitting analysis for formulation F9 fitted in the zero order model and korsemeyer- peppas model. The " $n$ " values obtained from the peppas-korsemeyer equation suggested that, drug release was non-fickian diffusion mechanism. Successful formulation was found stable after evaluation for physicochemical parameters when kept for 30 days at room temperature, $40^{\circ} \mathrm{C}$ and $2-8^{\circ} \mathrm{C}$.
\end{abstract}

INTRODUCTION: ${ }^{\mathbf{1 , 2 , 3 , 4}}$ Over the past 30 years, as the expense and complication involved in marketing new entities have increased with concomitant recognition of the therapeutics advantages of controlled drug delivery, greater attention has been focused on development of sustained or controlled drug delivery system. Sustained release technology is relatively new field and as a consequence, research in the field has been extremely fertile and has produced many discoveries. With many drugs, the basic goal is to achieve a steady state blood level that is therapeutically effective and non-toxic fir an extended period of time.

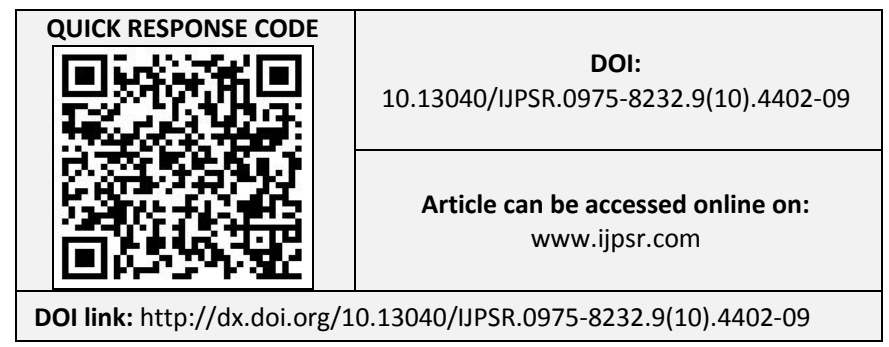

The design of proper dosage form is an important element to accomplish this goal. Sustained release, sustained action, prolonged action, controlled release, extended action, timed release and depot dosage form are term used to identify drug delivery system that are designed to achieve prolonged therapeutic effect by continuously releasing medication over an extended period of time after administration of a single dose.

In the case of oral sustained released dosage form, an effect is for several hours depending upon residence time of formulation in the GIT. Physician can achieve several desirable therapeutics advantages by prescribing sustained release dosage form. Since, the frequency of drug administration is reduced, patient's compliances can be improved and the drug administration can be made more convenient as well. The blood level oscillation characteristics of multiple dosing form of conventional dosage form is reduced, because more even blood level is maintained in the design of 
sustained release dosage form. The total amount of drug administered, thus maximum availability with a minimum dose. In addition, the safety margin of high potency drug can be increased and the incidence of both local and systemic adverse effects can be reduced in sensitive patients. Overall, increased administration of sustained release dosage form gives increased reliability.

Sustained Release: SRF's describes the slow release of a drug substance from a dosage form to maintain therapeutic response for extended period of time. Time depends on the dosage form. In oral form it is in hours, and in parenterals it is in days and months. Ex: Aspirin SR, Dextrin SR.

\section{Advantages:}

- Decreased local and systemic side effects.

- Better drug utilization.

- Improved efficiency in treatment.

\section{Disadvantages:}

- Decrease systemic availability in comparison to immediate release convention as dosage forms.

- Retrieval of drug is difficult in case of toxicity in case of toxicity, poisoning or hypersensitive reaction.

- Reduced potential for dosage adjustment of drug normally administered in varying strengths.

\section{Potential Advantage of Sustained Release Dosage Form: ${ }^{5}$}

$\checkmark$ Avoid patient's compliance problem due to reduced frequency of dosing.

$\checkmark$ Blood level oscillation characteristics of multiple dosing of conventional dosage form is reduced because a more even blood level is maintained.

$\checkmark$ Employ a less total drug.

$\checkmark$ Minimize or eliminate local or systemic side effects.

$\checkmark$ Minimize drug accumulation with chronic dosing.

$\checkmark$ Obtained less potential of reduction in drug activity with chronic use.
Improved efficiency in treatment.

- Cure or control condition more promptly.

- Improved control of condition i.e. reduced fluctuation in drug level

- Improved bioavailability of some drugs.

Make a use of special effects, sustained release aspect for relief of arthritis by dosing before bedtime.

$\checkmark$ Economy.

$\checkmark$ Overall, administrations of sustained release form enable increased reliability of therapy.

Recent Trends in Sustained Drug Delivery System: Sustained release dosage forms are categorized as:

1. Single unit dosage form.

2. Multiple unit dosage form.

3. Mucoadhesive system.

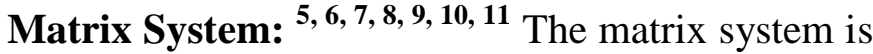
most often used for a drug-controlled release from a pharmaceutical dosage form. Among the innumerable method used in controlled release drug from pharmaceutical dosage form, the matrix system is the most frequently applied; it is release system for delay and control of the release of the drug that is dissolved or dispersed in a resistant support to disintegration. To define matrix, it is necessary to know the characters that differentiate it from other controlled release dosage forms. Hence the following must be considered:

- The chemical nature of support (generally, the support are formed by polymeric net).

- The physical state of drug (dispersed under molecular or particulate form or both).

- The matrix shape and alteration in volume as a function of time.

- The route of administration (oral administration remains the most widely used but other route are adaptable).

- The release kinetic model.

\section{Advantages of Matrix System:}

- The interest awakened by matrix system in last few years is completely justified in view of the 
major advantages. Among these, the following stand out.

- With proper control of manufacturing process, reproducible release profiles are possible.

- There is no risk of "dumping" of a large part of dose, through the structure makes the immediate release of a small amount of active principle unavoidable.

- Their capacity to incorporate active principle is large, which suits them to delivery of large dosage.

\section{TABLE 1: CLASSIFICATION OF MATRIX SYSTEM}

\begin{tabular}{|c|c|c|}
\hline 1 & Mineral matrix & $\begin{array}{l}\text { Drug retained in the support. Drug } \\
\text { adsorbed on the support }\end{array}$ \\
\hline 2 & Lipidic matrix & $\begin{array}{c}\text { Delivery by diffusion. Delivery by } \\
\text { surface erosion }\end{array}$ \\
\hline 3 & $\begin{array}{l}\text { Hydrophilic } \\
\text { matrix }\end{array}$ & $\begin{array}{c}\text { Unlimited swelling, delivery by } \\
\text { diffusion. Limited swelling controlled } \\
\text { delivery through swelling }\end{array}$ \\
\hline 4 & Inert matrix & Controlled delivery by diffusion \\
\hline 5 & $\begin{array}{l}\text { Biodegradable } \\
\text { matrix }\end{array}$ & Non-lipidic \\
\hline
\end{tabular}

Literature Review: 15, 16, 17, 18, 19, 20 Literature search reveals that the usage of various excipients like HPMC, sodium alginate, carrageenan, xanthan gum, etc. has shown a sustained release of drug and thus increased the duration of action of required drug for long hours.

\section{MATERIALS AND METHODS:}

TABLE 2: LIST OF CHEMICALS

\begin{tabular}{cc}
\hline Materials & Company Name \\
\hline Baclofen & Micro Lab, Hosur \\
HPMC K4M \& HPMC K15M & MSN Labs Ltd., Hyderabad \\
Lactose & MSN Labs Ltd., Hyderabad \\
Polyvinylpyrollidine-k-30 & MSN Labs Ltd., Hyderabad \\
Talc \& mannitol & Active Pharma Labs \\
Magnesium stearate & Active Pharma Labs \\
\hline
\end{tabular}

TABLE 3: LIST OF EQUIPMENTS

\begin{tabular}{cc}
\hline Equipment & Company name \\
\hline UV/Vis double beam & Shimadzu 1800 \\
spectrophotometer & Shimadzu \\
FTIR & Cadmach \\
Compression machine & Electro Lab \\
Tap density tester & Electro Lab \\
Tablet dissolution tester USP & Kimaya Engineers \\
Hydraulic press & Monsanto hardness tester \\
Hardness tester & Roche friability tester \\
Friability tester & Nutronics and Sisca \\
Melting point apparatus & Nutronics, DTC-201 \\
Tray dryer & Amtiq \\
Weighing balance & Labindia-DT 1000 \\
\hline
\end{tabular}

Formulation Procedure: ${ }^{12}$ Different formulations (F1-F12) were prepared by wet granulation method. Table 4 shows composition of each formulation. The formulations are composed of polymers HPMC K4M, sodium alginate, HPMC $\mathrm{K} 15 \mathrm{M}$ in the ratio $0: 0.5,1: 1,1: 1.5$ and $1: 2$ in various percentages.

All powders were passed through 12-mesh sieve. Weigh accurate amounts of excipients, Baclofen and mix with diluent and polymer (HPMC K4 M) for five minutes. Add the binder PVP K 30 and water to above mixture. Dump mass was passed through sieve no.12 and going to dry by using tray dryer. After drying add magnesium stearate and talc to the granules and sieve through sieve no. 20 . The resulting granules were then compressed.

\section{Pre-compression Studies:}

Angle of Repose: Flow property was determined by measuring the angle of repose.

$$
\operatorname{Tan}(\theta)=\mathrm{h} / \mathrm{r}
$$

Where, $\theta=$ Angle of repose, $\mathrm{h}=$ Height of heap, $\mathrm{r}=$ Radius of pile.

Bulk Density: Bulk density is a ratio of given mass of powder and its bulk volume.

$$
\text { Bulk density }=\mathrm{M} / \mathrm{V}_{0}
$$

$\mathrm{M}=$ Mass of the powder, $\mathrm{V}_{0}=$ Bulk volume of powder.

Tapped Density: it is generally given by the equation:

$$
\text { Tapped density }=\mathrm{M} / \mathrm{V}_{\mathrm{r}}
$$

$\mathrm{M}=$ Mass of powder, $\mathrm{V}_{\mathrm{r}}=$ final tapping volume of powder.

Compressibility Index and Hausner Ratio: To measure the unsettled apparent volume, $\left(\mathrm{V}_{0}\right)$ and the final tapped volume, $\left(\mathrm{V}_{\mathrm{f}}\right)$ of the powder after tapping the material until no further volume changes occur given by the expression as follows.

$$
\begin{gathered}
\text { Compressibility index }=\frac{1-\text { Bulk density }}{\text { Tapped density }} \times 100 \\
\text { Hausner ratio }=\frac{\text { Tapped density }}{\text { Bulk density }}
\end{gathered}
$$


TABLE 4: VARIOUS FORMULATIONS OF BACLOFEN MATRIX TABLETS

\begin{tabular}{|c|c|c|c|c|c|c|c|c|c|c|c|c|}
\hline Ingredients (mg) & $\mathbf{F}_{1}$ & $\mathbf{F}_{2}$ & $\mathbf{F}_{3}$ & $\mathbf{F}_{4}$ & $\mathbf{F}_{5}$ & $\mathbf{F}_{6}$ & $\mathbf{F}_{7}$ & $\mathbf{F}_{8}$ & $\mathbf{F}_{9}$ & $\mathbf{F}_{10}$ & $F_{11}$ & $\mathbf{F}_{12}$ \\
\hline Baclofen & 25 & 25 & 25 & 25 & 25 & 25 & 25 & 25 & 25 & 25 & 25 & 25 \\
\hline HPMC K4 & 12.5 & 25 & 37.5 & 50.0 & - & - & - & - & - & - & - & - \\
\hline HPMC K15 & - & - & - & - & - & - & - & - & 12.5 & 25 & 37.5 & 50 \\
\hline PVP K 30 & 5 & 5 & 5 & 5 & 5 & 5 & 5 & 5 & 5 & 5 & 5 & 5 \\
\hline Talc & 2 & 2 & 2 & 2 & 2 & 2 & 2 & 2 & 2 & 2 & 2 & 2 \\
\hline
\end{tabular}

TABLE 5: FLOW PROPERTIES DETERMINATION

\begin{tabular}{cccc}
\hline $\begin{array}{c}\text { Flow } \\
\text { properties }\end{array}$ & $\begin{array}{c}\text { Angle of } \\
\text { repose }\end{array}$ & $\begin{array}{c}\text { Carr's } \\
\text { index }\end{array}$ & $\begin{array}{c}\text { Hausner } \\
\text { ratio }\end{array}$ \\
\hline Excellent & $25-30$ & $<10$ & $1.00-1.11$ \\
Good & $31-35$ & $11-15$ & $1.12-1.18$ \\
Fair & $36-40$ & $16-20$ & $1.19-1.25$ \\
Passable & $41-45$ & $21-26$ & $1.26-1.34$ \\
Poor & $46-55$ & $26-31$ & $1.35-1.45$ \\
Very poor & $56-65$ & $32-37$ & $1.46-1.49$ \\
Very very poor & $>66$ & $>38$ & $>1.6$ \\
\hline
\end{tabular}

\section{Post-compression Parameters:}

Hardness: The hardness of the tablet was determined using a Monsanto hardness tester. It is expressed in $\mathrm{kg} / \mathrm{cm}^{2}$.

Friability (F): This test is closely related to tablet hardness and designed to evaluate the ability of the to withstand abrasion is determined by the formula.

$$
\% \text { friability }=\left(\mathrm{W}_{1}-\mathrm{W}_{2}\right) / \mathrm{W}_{1} \times 100
$$

$\mathrm{W}_{1}=$ Weight of tablets before test, $\mathrm{W}_{2}=$ Weight of the tablets after the test.

Weight Variation Test: Comparison of the weight of the individual tablets (xi) of sample of tablets with an upper and lower percentage limit of the observed sample average (x-mean).

TABLE 6: LIMIT FOR TABLET WEIGHT VARIATION TEST

\begin{tabular}{cc}
\hline Average weight of tablet (mg) & \% Difference allowed \\
\hline 130 or less & $10 \%$ \\
$130-324$ & $7.5 \%$ \\
$>324$ & $5 \%$ \\
\hline
\end{tabular}

Thickness: The thickness of the tablets was measured by screw gauge. It is expressed in $\mathrm{mm}$.

Content Uniformity: Used to ensure that every tablet contains the amount of drug substances indeed with little variation among tablets with in batch.

In-vitro Dissolution Test: The USP type II rotating paddle method was used to study the drug release from the tablet. The dissolution medium consisted of $900 \mathrm{ml}$ of phosphate buffer $\mathrm{pH}$ 6.8. The release study was performed at $37 \pm 0.5^{\circ} \mathrm{C}$ with a rotation speed of $50 \mathrm{rpm}$. Aliquots were withdrawn at regular time intervals and replaced with fresh medium to maintain sink conditions. The samples were filtered with appropriate dilutions with phosphate buffer $\mathrm{pH} \quad 6.8$ and were analysed spectrophotometrically at $276 \mathrm{~nm}$.

\begin{tabular}{lc} 
TABLE 7: DISSOLUTION & STUDY \\
MATRIX TABLETS & BACLOFEN \\
\hline Bath temperature & $37^{\circ} \mathrm{C} \pm 5$ \\
Dissolution media & $6.8 \mathrm{p} \mathrm{H}$ phosphate buffer \\
Volume of dissolution & $900 \mathrm{ml}$ \\
Aliquot withdrawn & $5 \mathrm{ml}$ \\
Dissolution apparatus & USP paddle type II \\
Revolutions per minute & 5 \\
\hline
\end{tabular}

\section{RESULTS AND DISCUSSION:}

Determination of $\lambda_{\max }$ of Baclofen $6.8 \mathrm{pH}$ Buffer: Stock Solution: Baclofen in 6.8 phosphate buffer $(100 \mathrm{mg}$ in $100 \mathrm{ml})$. From the stock solution 100 $\mu \mathrm{g} / \mathrm{ml}$ solution of Baclofen was prepared by doing suitable dilutions with the buffer and scanned between 200-400 $\mathrm{nm}$. The absorption maxima of $220 \mathrm{~nm}$ was found and used for further studies.

Preparation of 6.8-pH Buffer Solution: Dissolve $6.8 \mathrm{~g}$ of potassium dihydrogen phosphate in $250 \mathrm{ml}$ of water and stirred it for $5 \mathrm{~min}$. Dissolve $2 \mathrm{gm}$ of $\mathrm{NaOH}$ in $250 \mathrm{ml}$ water. Take $250 \mathrm{ml}$ of potassium dihydrogen phosphate and to it add $112 \mathrm{ml}$ of $\mathrm{NaOH}$ solution in $1000 \mathrm{ml}$ flask and make up a volume up to $1000 \mathrm{ml}$.

Preparation of Standard Curve of Baclofen in 6.8 pH Buffer: For the standard graph, Baclofen $100 \mathrm{mg}$ was accurately weighed and dissolved in $100 \mathrm{ml}$ of $6.8 \mathrm{pH}$ buffer. From the working standard drug solution (1 $\mathrm{mg} / \mathrm{ml})$, different concentration of Baclofen viz, 2, 3, 4........up to 
$6 \mathrm{mcg} / \mathrm{ml}$ were prepared and made up to volume with $6.8 \mathrm{pH}$ buffer. The absorbance of the different concentration of Baclofen was measured at the $220 \mathrm{~nm}$ against the reagent blank. The absorbances, which were found, are given in Table and the graph plotted of concentration vs. absorbance is shown in Fig. 1.

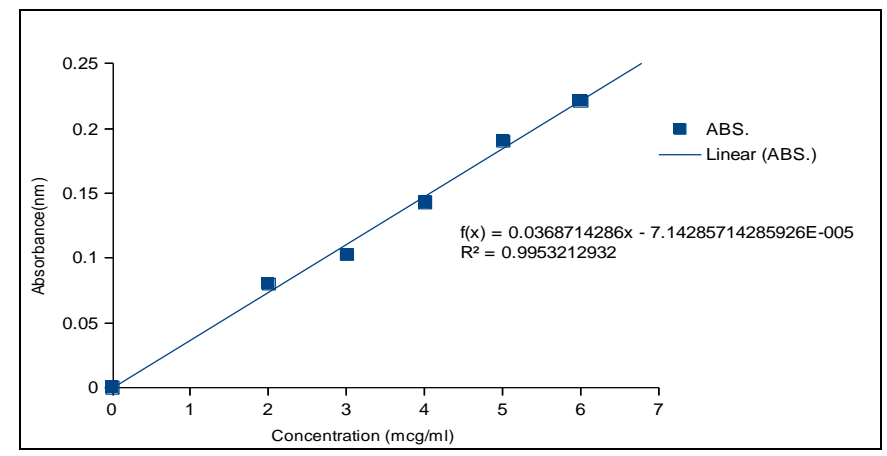

FIG. 1: STANDARD GRAPH OF BACLOFEN IN $6.8 \mathrm{pH}$ BUFFER
Pre-compression Parameters: Pre compression parameters of all formulations blend were conducted for angle of repose, bulk density, tapped density, compressability index and hausners ratio. The two most important attributes for the direct compression formula are good flow and good compressability. Inter particulate interactions that influence the bulking properties of a powder with powder flow. A comparison of bulk density and tapped density can give a measure of the relative importance of this interaction in given powder. The powder flow depends on three general areas. The physical property of particle (ex. shape, size, compressability), the bulk powder properties (ex. size distribution, compaction), and the processing environment (storage, humidity). Pre compression parameter are evaluated, these are mentioned in following Table 8.

TABLE 8: PRE COMPRESSION PARAMETERS OF BACLOFEN TABLETS

\begin{tabular}{cccccc}
\hline Formulation & Bulk density & Tapped density & Carr's index & Hausner ratio & Angle of repose \\
\hline $\mathrm{F}_{1}$ & 0.303 & 0.370 & 16.75 & 1.18 & 30 \\
$\mathrm{~F}_{2}$ & 0.312 & 0.344 & 10 & 1.11 & 31 \\
$\mathrm{~F}_{3}$ & 0.294 & 0.375 & 15.67 & 1.20 & 29 \\
$\mathrm{~F}_{4}$ & 0.333 & 0.370 & 13.28 & 1.15 & 34 \\
$\mathrm{~F}_{5}$ & 0.312 & 0.380 & 17.64 & 1.22 & 32 \\
$\mathrm{~F}_{6}$ & 0.322 & 0.357 & 14.53 & 1.18 & 31 \\
$\mathrm{~F}_{7}$ & 0.294 & 0.388 & 16.14 & 1.21 & 33 \\
$\mathrm{~F}_{8}$ & 0.315 & 0.373 & 15.45 & 1.15 & 30 \\
$\mathrm{~F}_{9}$ & 0.323 & 0.355 & 17.55 & 1.20 & 28 \\
$\mathrm{~F}_{10}$ & 0.296 & 0.336 & 14.33 & 1.20 & 30 \\
$\mathrm{~F}_{11}$ & 0.325 & 0.363 & 17.45 & 1.18 & 1.22 \\
$\mathrm{~F}_{12}$ & 0.328 & 0.354 & 15.28 & & 30 \\
\hline
\end{tabular}

Post-compression Parameters: Evaluation of tablets was done by studying various parameters like weight variation, thickness, hardness, friability and \% drug content and the results were presented in Table 9 and all the results were found to be within the Pharmacopeial standards.

TABLE 9: POST-COMPRESSION PARAMETERS OF BACLOFEN TABLETS

\begin{tabular}{cccccc}
\hline Formulation & Hardness $\left(\mathbf{k g} / \mathbf{c m}^{\mathbf{2}}\right)$ & Friability $\mathbf{( \% )}$ & Thickness $(\mathbf{m m})$ & Wt. Var. (avg. wt) $(\mathbf{m g})$ & Drug content \% \\
\hline $\mathrm{F}_{1}$ & 6.93 & 0.64 & 2.43 & 203 & 201 \\
$\mathrm{~F}_{2}$ & 6.83 & 0.58 & 2.56 & 202 & 97.92 \\
$\mathrm{~F}_{3}$ & 6.66 & 0.62 & 2.53 & 201 & 98.42 \\
$\mathrm{~F}_{4}$ & 6.76 & 0.53 & 2.53 & 202 & 96.83 \\
$\mathrm{~F}_{5}$ & 6.83 & 0.56 & 2.50 & 203 & 96.65 \\
$\mathrm{~F}_{6}$ & 6.66 & 0.61 & 2.46 & 201 & 98.22 \\
$\mathrm{~F}_{7}$ & 6.83 & 0.59 & 2.43 & 201 & 96.90 \\
$\mathrm{~F}_{8}$ & 6.65 & 0.58 & 2.52 & 202 & 98.80 \\
$\mathrm{~F}_{9}$ & 6.85 & 0.56 & 2.52 & 200 & 97.60 \\
$\mathrm{~F}_{10}$ & 6.91 & 0.62 & 2.45 & 201 & 95.20 \\
$\mathrm{~F}_{11}$ & 6.89 & 0.65 & 2.55 & 2.71 & 96.50 \\
$\mathrm{~F}_{12}$ & 6.95 & 0.60 & &
\end{tabular}

Spectra of Pure drug of FTIR Baclofen: The IR spectrum of pure drug were studied. The characteristic absorption peaks of Baclofen were obtained at $2156.99 \mathrm{~cm}^{-1}, 1160.94 \mathrm{~cm}^{-1}, 1093.44$ $\mathrm{cm}^{-1}, 1001.84 \mathrm{~cm}^{-1}, 945.91 \mathrm{~cm}^{-1}, 834.06 \mathrm{~cm}^{-1}$. The peaks obtained in the spectra of each formulation 
correlates with the peaks of drug spectrum. This indicates that the drug was compatible with the formulation components.

Drug - Excipient Compatibility Study: Drugexcipient compatibility studies were carried out by FT-IR spectroscopy. The IR spectrum of pure drug and physical mixture of drug and polymer were studied. The peaks obtained in the spectra of each formulation correlates with the peaks of drug spectrum. This indicates that the drug was compatible with the formulation components shown in Fig. 3 and 4.

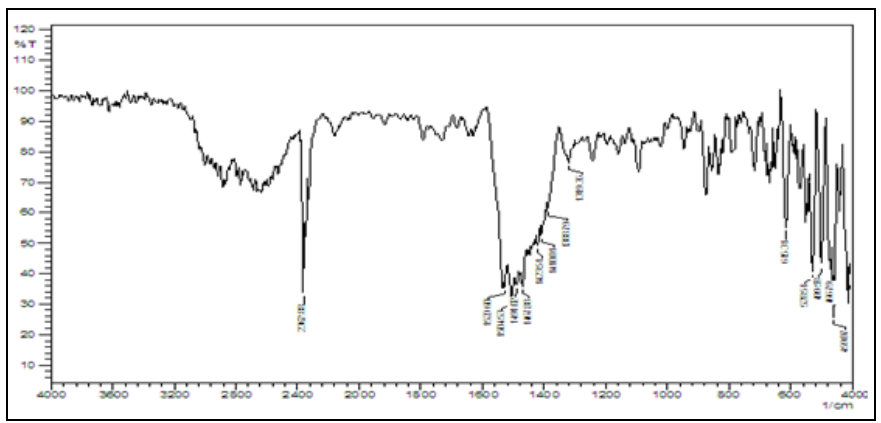

FIG. 2: SPECTRA OF PURE DRUG OF FTIR BACLOFEN

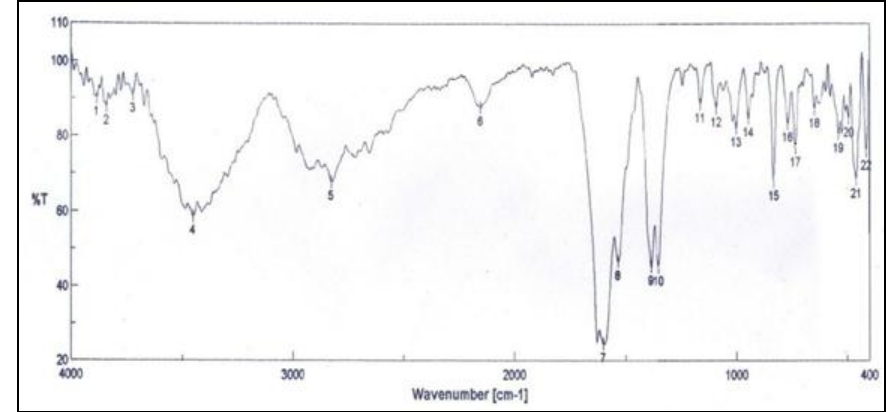

FIG. 3: SPECTRA OF PURE DRUG + SODIUM ALGINATE

In-vitro Dissolution Study and Kinetic Modeling of Drug Release: ${ }^{13,}{ }^{14}$ All the formulations of Baclofen were subjected to in-vitro release studies these studies were carried out using dissolution apparatus. The dissolution medium consisted of $900 \mathrm{ml}$ of standard buffer $\mathrm{pH} 1.2$ for the first $2 \mathrm{~h}$, followed by $\mathrm{pH} 6.8$ for remaining period of time. The release of Baclofen from sustained release tablet of the various formulations varied according to the ratio and degree of the different polymer. The formulation F9 having swellable polymer as

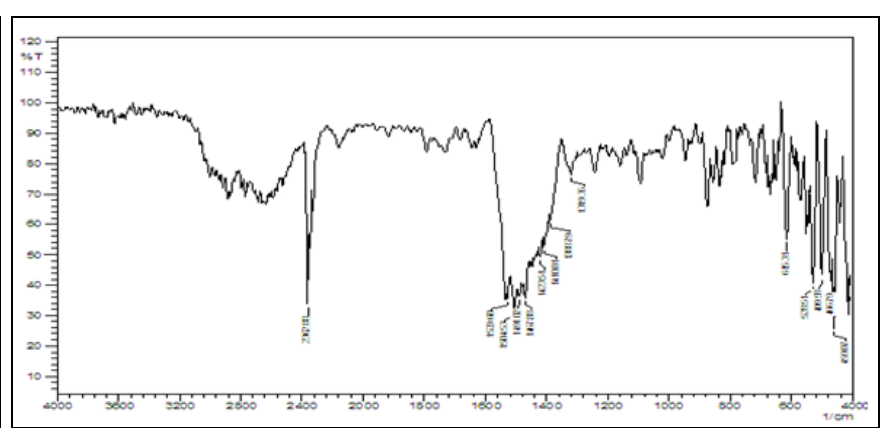

FIG. 4: SPECTRA OF PURE DRUG + HPMC K 15

HPMC K15. The optimized formulation F9 which releases the Baclofen in a sustained manner in $1^{\text {st }} \mathrm{h}$ it releases $31.63 \%$ but $98.83 \%$ release after $12 \mathrm{~h}$. The polymer HPMC K15 M sustain the relax up to $12 \mathrm{~h}$. The in-vitro drug release profile of Baclofen $\left(\mathrm{F}_{1}-\mathrm{F}_{4}\right)$, Baclofen + sodium alginate $\left(\mathrm{F}_{5}-\mathrm{F}_{8}\right)$ and Baclofen + HPMC K15 M $\left(\mathrm{F}_{9}-\mathrm{F}_{12}\right)$ were shown in Fig. 5, $6 \& 7$ and Table 10. Formulation $F_{9}$ has shown the best dissolution profile which is represented in Fig. 8. The kinetic profile of all formulations were shown in Table 11.

TABLE 10: DISSOLUTION OF FORMULATIONS IN 6.8 PHOSPHATE BUFFER

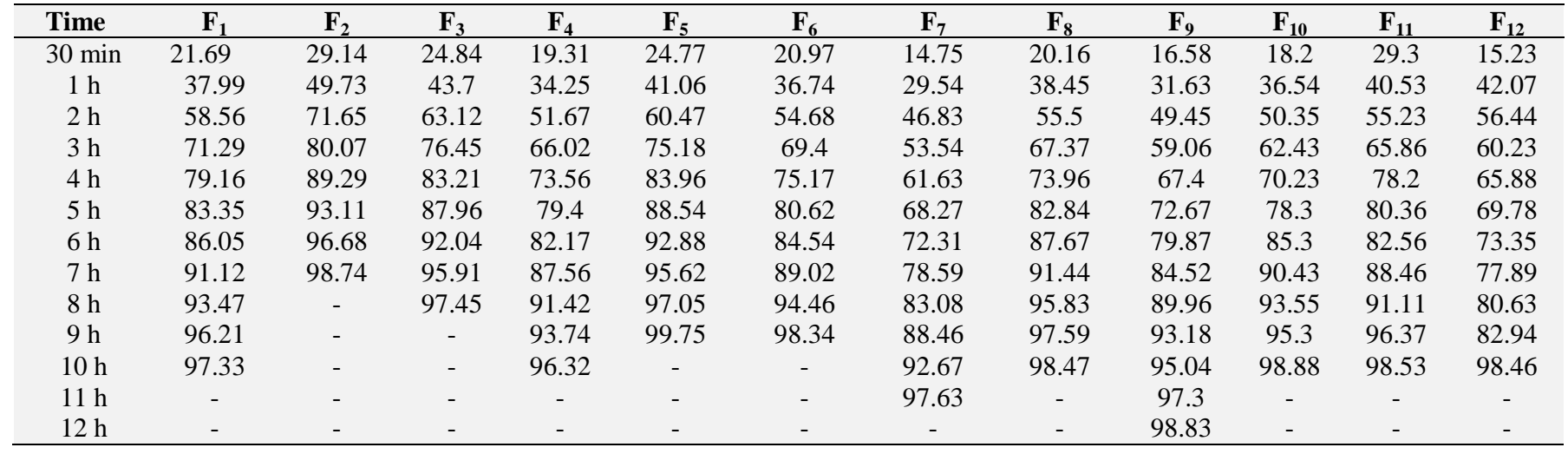




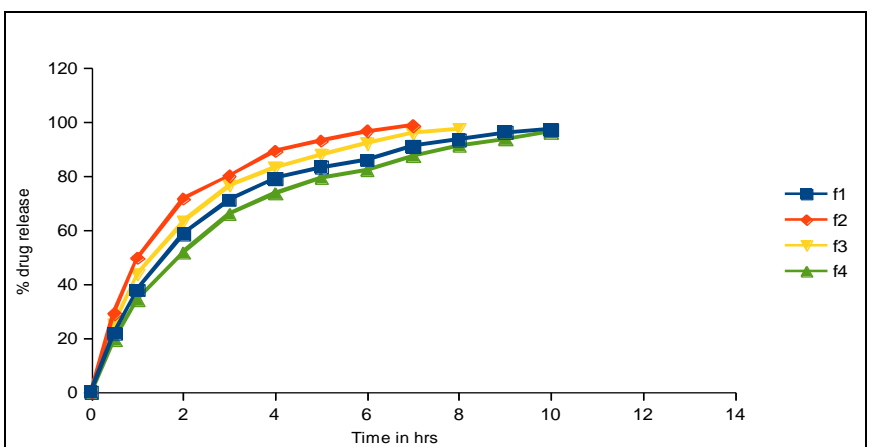

FIG. 5: IN-VITRO DRUG RELEASE PROFILE OF BACLOFEN F1-F4

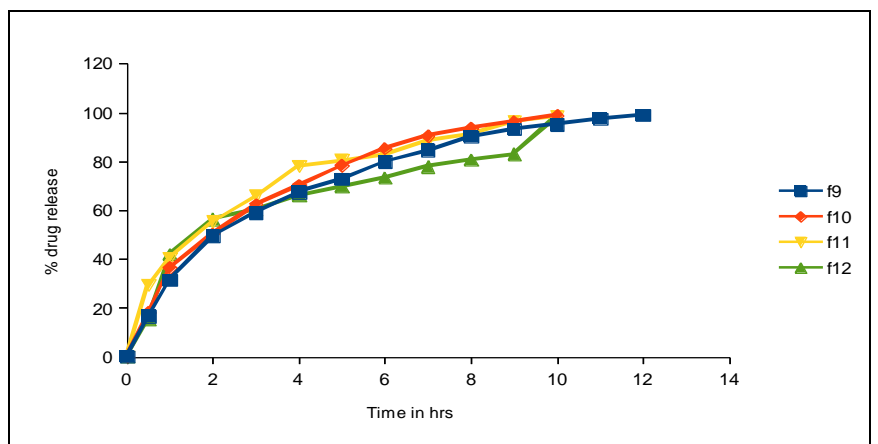

FIG. 7: HPMC K15 M DISSOLUTION PROFILE

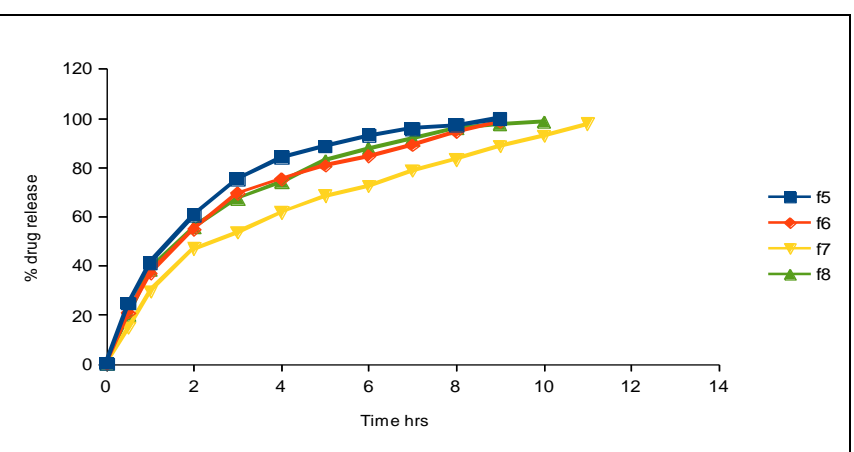

FIG. 6: SODIUM ALGINATE DISSOLUTION PROFILE F5-F8

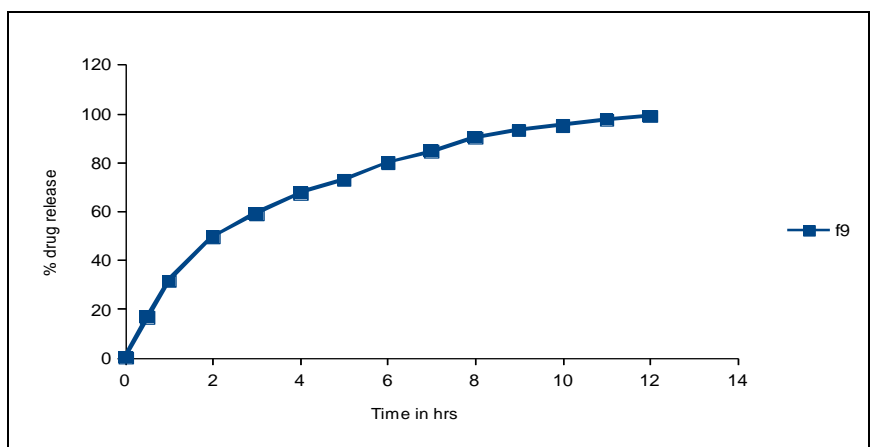

FIG. 8: BEST FORMULATION DISSOLUTION PROFILE (F9)

TABLE 11: RELEASE KINETICS DATA OF BACLOFEN

\begin{tabular}{cccccc}
\hline Formulation & Zero Order & First Order & Higuchi Matrix & Peppas plot $\mathbf{R}^{2}$ value & Peppas plot n value \\
\hline $\mathrm{F}_{1}$ & 0.802 & 0.991 & 0.956 & 0.947 & 0.947 \\
$\mathrm{~F}_{2}$ & 0.708 & 0.984 & 0.959 & 0.947 & 0.947 \\
$\mathrm{~F}_{3}$ & 0.816 & 0.993 & 0.965 & 0.953 & 0.953 \\
$\mathrm{~F}_{4}$ & 0.833 & 0.974 & 0.970 & 0.960 & 0.960 \\
$\mathrm{~F}_{5}$ & 0.808 & 0.999 & 0.960 & 0.957 & 0.957 \\
$\mathrm{~F}_{6}$ & 0.856 & 0.926 & 0.979 & 0.967 & 0.967 \\
$\mathrm{~F}_{7}$ & 0.901 & 0.896 & 0.992 & 0.969 & 0.958 \\
$\mathrm{~F}_{8}$ & 0.840 & 0.980 & 0.973 & 0.958 & 0.968 \\
$\mathrm{~F}_{9}$ & 0.878 & 0.963 & 0.986 & 0.968 & 0.965 \\
$\mathrm{~F}_{10}$ & 0.865 & 0.895 & 0.955 & 0.940 & 0.956 \\
$\mathrm{~F}_{11}$ & 0.901 & 0.886 & 0.980 & 0.956 & 0.948 \\
$\mathrm{~F}_{12}$ & 0.885 & 0.950 & 0.968 & 0.968 & \\
\hline
\end{tabular}

SUMMARY AND CONCLUSION: The sustained release tablet containing Baclofen matrix were successfully prepared by wet granulation method. The physiochemical evaluation results for the granules blend of all trials pass the official limits in angle of repose, bulk density, compressibility index. The prepared tablets were also maintained the physiochemical properties such as thickness, hardness, weight variation, friability.

Increasing the amount of HPMC and sodium alginate in solid matrix tablet decreased the release rate of the drug. The formulation F9 having swellable polymer as HPMC K15 optimized formulation which releases the Baclofen in a sustained manner in first hour it released $31.63 \%$ but $98.83 \%$ released after $12 \mathrm{~h}$. The polymer HPMC K15 M sustain the release upto $12 \mathrm{~h}$.

ACKNOWLEDGEMENT: We are thankful to the Active Pharma Labs, MSN Labs, Hyderabad and Micro Labs for providing required chemical samples. Also we sincerely thank our KLR pharmacy college for providing necessary equipments and their support in the fulfilment of this research work successfully.

CONFLICT OF INTEREST: All persons who meet authorship criteria are listed as authors, and all authors certify that they have participated sufficiently in the work to take public responsibility for the content, including participation in the 
concept, design, analysis, writing or revision of the manuscript. Furthermore, each author certifies that this material or similar material has not been and will not be submitted to or published in any other publication.

\section{REFERENCES:}

1. Chien YWL: Novel drug delivery system. Revised and Expanded, Edition 2 ${ }^{\text {nd }}, 1992: 139-140$.

2. Remington: The science and practice of pharmacy. Edition $20^{\text {th }}$, Vol. I, 903-913.

3. Brahmankar DM and Jaiswal SB: In biopharmaceutics and pharmacokinetics. A Treatise, Vallabh Prakashan, Edition $1^{\text {st }}, 1995: 347-352$.

4. Lee VH and Robinson JR: Sustained and controlled release drug delivery system. Marcel Dekker, Newyork, 71-121.

5. Lachman L, Liberman HA and Kanig JL: the theory and practice of industrial pharmacy. Varghese Publishing House Bombay, Fourth Indian Reprint 1991: 430.

6. Liberman HA, Lachman L and Joseph B: Pharmaceutical dosage form: Tablets. Expanded \& Revised, Marcel Dekker, Inc, Newyork, Edition2 ${ }^{\text {nd }}$, Vol.1, 136-154.

7. Aulton ME: Pharmaceutics: The design and manufacture of medicines. Elsevier Publications, Edition $3^{\text {rd }}$, 2001: 291295.

8. Ansel HC, Allen LV and Popovich NG: Pharmaceutical dosage form and drug delivery systems. Lippincolt Williams \& Wilkins, Edition $7^{\text {th }}, 229-243$.

9. Jain NK: Controlled and novel drug delivery. Vol. 1-2, CBS 2002: 676-698.
10. British Pharmacopeia, London, Medicines \& Healthcare Products Regulatory Agency, TSO, Vol. 2, 2009.

11. Indian Pharmacopoeia, Government of India, Ministry of health and family welfare. The Controller of Publications, New Delhi, Edition $4^{\text {th }}, 1996$.

12. Dhake AS and Behl AK: Indian Drug. 2005; 42(5): 316318.

13. Drug Facts and comparisons: Edition $50^{\text {th }}, 1996: 1785-90$.

14. Ainley W and Weller PJ: Hand book of pharmaceutical excipients. edition $4^{\text {th }}, 1994: 71-73,78-80,82-83$.

15. Patel K: An overview extend release matrix technology. International Journal of Pharmaceutical \& Chemical Sciences 2012; 1(2): 828-843.

16. Abdelkader $\mathrm{H}$, Youssef $\mathrm{O}$, Abdulla and Sale $\mathrm{H}$ : Formulation of controlled-release Baclofen matrix tablets: Some hydrophilic polymers on the release rate and in-vitro evaluation. 2007; 156-167.

17. Ishikawa $\mathrm{T}$, Watanabe $\mathrm{Y}$, Takayama $\mathrm{K}$, Endo $\mathrm{H}$ and Matsumoto M: Effect of hydroxypropyl methylcellulose (HPMC) on the release profiles and bioavailability of a poorly water-soluble drug from tablets prepared using marigold and HPMC. International $\mathrm{J}$ of Pharmaceutics 2000; 202: 173-178

18. Liu L and Xiangning CSU: Preparation of belayed-core osmotic pump tablet y coating the indented core tablet, International Jour of Pharmaceutics 2008; 352: 225-230.

19. Remufifin C, Bretal MJ, Nfifiez A and Jato JLV: Accelerated stability study of sustained-release nifedipine tablets prepared with Gelucire. International Journal of Pharmaceutics 1992; 80: 151-159.

20. Liu L, Ku J, Khan G, Lee B, Rhee JM and Lee HB: Nifedipine controlled delivery by sandwiched osmotic tablet system. Journal of Controlled Release 2000; 68: 145-156.

\section{How to cite this article:}

Shankar KR, Madhan K and Swetha G: Formulation and evaluation of sustained release matrix tablets of Baclofen. Int J Pharm Sci \& Res 2018; 9(10): 4402-09. doi: 10.13040/IJPSR.0975-8232.9(10).4402-09.

All @ 2013 are reserved by International Journal of Pharmaceutical Sciences and Research. This Journal licensed under a Creative Commons Attribution-NonCommercial-ShareAlike 3.0 Unported License.

This article can be downloaded to ANDROID OS based mobile. Scan QR Code using Code/Bar Scanner from your mobile. (Scanners are available on Google Playstore) 